\title{
Use of emulsifier and lipase in feeds for broiler chickens
}

\section{Uso de emulsificante e lipase em rações de frangos de corte}

\author{
Lennon Santos de Oliveira ${ }^{1}$; Eric Márcio Balbino ${ }^{2}$; Tamiris Natalice Santos Silva ${ }^{3}$; \\ Lin Ily ${ }^{3}$; Tatiana Cristina da Rocha ${ }^{4}$; Evani Souza de Oliveira Strada \\ Alexandre Moraes Pinheiro ${ }^{4}$; Jerônimo Ávito Gonçalves de Brito ${ }^{4 *}$
}

\begin{abstract}
The objective of this study was to evaluate the effect of exogenous emulsifier and lipase in diets on performance, digestibility, and organ biometry of broiler chickens. A completely randomised design with seven treatments and seven replications was adopted. The treatments were as follows: T1 (positive control; PC): $3000,3100,3200$, and $3250 \mathrm{Kcal}$ of metabolisable energy (ME) $\mathrm{kg}^{-1}$ of diet for phases 1 to 10, 11 to 21, 22 to 31, and 32 to 37 days, respectively; T2: PC with reduction in ME of $30 \mathrm{Kcal} \mathrm{kg}^{-1}$ of diet; T3: PC with reduction in ME of $60 \mathrm{Kcal} \mathrm{kg}^{-1}$ of feed; T4 (negative control; NC): PC with reduction in ME of $90 \mathrm{Kcal} \mathrm{kg}^{-1}$ of feed; T5: NC with inclusion of exogenous lipase (10000 $\left.\mathrm{U} \mathrm{kg}^{-1}\right)$; T6: NC with inclusion of emulsifier $\left(250 \mathrm{~g} \mathrm{t}^{-1}\right)$; and T7: $\mathrm{NC}$ with inclusion of lipase $\left(10000 \mathrm{U} \mathrm{kg}^{-1}\right)$ and emulsifier $\left(250 \mathrm{~g} \mathrm{t}^{-1}\right)$ in the period from 1 to 37 days of rearing. Performance characteristics (weight gain (WG), feed intake (FI), and feed conversion (FC)), carcass yield, cut yield, the relative weight of abdominal fat and organs (small intestine, liver, and pancreas), and relative intestinal length, in addition to dry matter digestibility (CDADM), ethereal extract (CDAEE), crude metabolisable energy (CMACE), and apparent metabolisable energy (AME) of the diets, were evaluated. In the initial phase, the CDAEE was higher for the PC group than for the emulsifier + lipase group. The AME determined in the final phase for the group supplemented with an emulsifier was higher by approximately $50 \mathrm{Kcal}$ (EM) than the NC group. The WG of the lipase group was similar to that of the PC group. However, the groups with emulsifier and emulsifier + lipase showed a lower WG than the PC group. The additives used did not recover the FC to the same level observed in the PC group. The reduction in $\mathrm{ME}$ of $90 \mathrm{Kcal} \mathrm{kg}^{-1}$ generated a lower WG and worse FC. The use of both an emulsifier and lipase together produced results like to the PC group. The biometrics of the organs and the carcass yield and cuts were not influenced by diets. Thus, it can be concluded that the inclusion of lipase and an emulsifier improves the performance of broilers given diets with reduced energy, although it does not improve the lipid utilisation of the diets. Key words: Poultry meat science. Exogenous enzyme. Performance.
\end{abstract}

\section{Resumo}

Objetivou-se com este estudo avaliar a utilização de emulsificante e lipase em rações sobre a digestibilidade, desempenho e biometria de órgãos para frangos de corte. Foi adotado um delineamento inteiramente casualizado, com sete tratamentos e sete repetições. Os tratamentos foram constituídos da

\footnotetext{
1 Discente de Mestrado, Programa de Pós-Graduação em Ciência Animal, Universidade Federal do Recôncavo da Bahia, UFRB, Cruz das Almas, BA, Brasil. E-mail: lennon.oliver@hotmail.com

2 Pós-Doutorando, Programa de Pós-Graduação em Ciência Animal, UFRB, Cruz das Almas, BA, Brasil. E-mail: embalbino@ yahoo.com.br

3 Discentes de Graduação em Zootecnia, UFRB, Cruz das Almas, BA, Brasil. E-mail: zootecsilva@gmail.com; linily93@gmail.com

4 Profs., Centro de Ciências Agrárias, Ambientais e Biológicas, UFRB, Cruz das Almas, BA, Brasil. E-mail: tatianarocha@ufrb. edu.br; evanistrada@ufrb.edu.br; amp@ufrb.edu.br; jeronimo@ufrb.edu.br

* Author for correspondence
}

Received: Oct. 10, 2018 - Approved: May 08, 2019 
seguinte forma: T1 (Controle Positivo - CP): 3000, 3100, 3200, 3250 Kcal de energia metabolizável (EM) $\mathrm{kg}^{-1}$ de ração para as fases 1 a 10, 11 a 21, 22 a 31 e 32 a 37 dias, respectivamente; T2: CP com redução de EM em $30 \mathrm{Kcal} \mathrm{kg}^{-1}$ de ração; T3: CP com redução de $60 \mathrm{Kcal} \mathrm{EM} \mathrm{kg}^{-1}$ de ração; T4 (Controle Negativo - CN): CP com redução de $90 \mathrm{Kcal} \mathrm{EM} \mathrm{kg}^{-1}$ de ração; T5: CN + inclusão de lipase exógena (10000 U $\left.\mathrm{kg}^{-1}\right)$; T6: CN com inclusão de emulsificante $\left(250 \mathrm{~g} \mathrm{t}^{-1}\right)$; T7: CN com a utilização de lipase (10000 U $\left.\mathrm{kg}^{-1}\right)$ e emulsificante $\left(250 \mathrm{~g} \mathrm{t}^{-1}\right)$ no período de 1 a 37 dias de criação. Foram avaliadas características de desempenho (ganho de peso (GP), consumo de ração (CR) e conversão alimentar (CA)), rendimento de carcaça, rendimento de cortes, peso relativo da gordura abdominal e de órgãos (intestino delgado, fígado e pâncreas), comprimento relativo do intestino e digestibilidade da matéria seca (CDAMS), do extrato etéreo (CDAEE) e metabolizabilidade da energia bruta (CMAEB) das rações. Na fase inicial, o CDAEE foram maiores para o grupo CP quando comparado ao grupo com emulsificante+lipase. A EMA determinada na fase final do grupo submetido ao uso de emulsificante apresentou superioridade em cerca de $50 \mathrm{Kcal}$ (EM) em comparação ao grupo CN. O GP do grupo lipase foi semelhante ao observado no grupo CP. Por outro lado, os grupos com emulsificante e emulsificante + lipase apresentaram menor GP quando comparado ao grupo $\mathrm{CP}$. Os aditivos utilizados não proporcionaram recuperação na $\mathrm{CA}$ àquela observada no grupo $\mathrm{CP}$. A redução de EMA em $90 \mathrm{Kcal} / \mathrm{kg}$ gerou menor GP e pior CA. O uso de aditivos em conjunto foi o grupo que mais aproximou ao desempenho observado no grupo CP. A biometria dos órgãos e o rendimento de carcaça e cortes não foram influenciados pelos grupos avaliados. Assim, podese concluir que a inclusão de lipase e emulsificante melhoram o desempenho em rações com redução de energia, embora não melhore o aproveitamento de lipídeos das rações.

Palavras-chave: Avicultura de corte. Enzima exógena. Desempenho.

\section{Introduction}

When formulating diets for broiler chickens, questions arise about the limits of energy utilisation by the birds, either due to the maximum peak of growth or to a physiological limitation due to the rate of synthesis of enzymes, including those related to lipid digestion (lipase), and the ability to synthesise and recirculate bile acids and salts, especially in young birds (MURAKAMI et al., 2009; UPADHAYA et al., 2017).

In this context, poultry production has been pursuing nutritional programmes that aim to boost digestion and lipid absorption, reduce costs, and minimise losses in the production process without compromising chicken performance. Therefore, exogenous lipase and emulsifier supplementation could benefit the energetic utilisation of the diets and influence the performance of the chickens.

The use of emulsifiers in diets can be considered a strategy to improve the digestibility of lipids by facilitating the action of lipase, in addition favouring the formation of micelles of lipolysis products, potentiating absorption by the intestinal mucosa (ZHAO; KIM, 2017; WANG et al., 2016).

The scientific literature contains a relatively small number of studies on the use of lipase (as a monocomponent) in feeds for broilers compared to the use of other exogenous enzymes (phytases, carbohydrases, proteases), and when used, lipase usually appears as a component of enzymatic complexes. However, there is a tendency in the industry to develop biotechnological processes and thereby provide lipases as feed additives (WANG et al., 2017). In combination with the use of an emulsifier, lipase could potentiate lipid digestibility and consequently the energy utilisation inherent to this nutrient.

Thus, with the use of lipase and an emulsifier, it would be possible to improve the lipid digestibility and, as a consequence, to provide the animals with a greater amount of metabolisable energy in diets with a reduced energy density, making it possible to restore performance, carcass characteristics, and the development of organs. 
The objective of this study was to evaluate the effect of supplementation with lipase and an emulsifier on performance, organ biometrics, carcass yield, cut yield, and abdominal fat deposition in the birds, and lipid digestibility and energy utilisation of the rations with a reduced level of metabolisable energy.

\section{Materials and Methods}

The experiment was carried out at the Poultry Sector of the Federal University of Recôncavo da Bahia (UFRB), located in the municipality of Cruz das Almas, Bahia (latitude: $12^{\circ} 40$ ' 12 " $\mathrm{S}$, longitude: $39^{\circ} 06^{\prime} 07^{\prime \prime} \mathrm{W}$, and altitude: $220 \mathrm{~m}$ ).

A total of 1960 one-day-old males of the Cobb $500 ®$ strain from a commercial hatchery weighing $40.04 \pm 0.341 \mathrm{~g}$ and previously vaccinated against the major health challenges of the region (Gumboro, Newcastle, infectious Bronchitis, and Marek) were used in the study. The birds were housed in a fowl shed, with a cement floor and clay roof, with dimensions of $9 \times 22 \mathrm{~m}$, divided into boxes of 1.55 $\times 1.66 \mathrm{~m}$ with 40 birds each, resulting in an initial density of 15.5 birds $\mathrm{m}^{-2}$. The boxes had a pendulum drinker (bell) and a tubular feeder and a reused bed of wood, with a height of approximately $5 \mathrm{~cm}$.

A total of 49 metabolic cages $(50 \times 50 \times 45 \mathrm{~cm})$ were used to determine the digestibility of nutrients and the metabolisable energy of the diets according to the evaluated treatments. Each cage contained a pressure drinker, a trough-type feeder, and a tray covered with plastic film under the screen floor for the collection of excreta.

A completely randomised experimental design with seven treatments and seven replications was adopted. The treatments were as follows: T1 (positive control; PC): 3000, 3100, 3200, and 3250 Kcal of metabolisable energy (ME) $\mathrm{kg}^{-1}$ of diet for phases 1 to 10,11 to 21,22 to 31 , and 32 to 37 days, respectively; T2: PC with a reduction in $\mathrm{ME}$ of $30 \mathrm{Kcal} \mathrm{kg}^{-1}$ of diet; T3: PC with a reduction in $\mathrm{ME}$ of $60 \mathrm{Kcal} \mathrm{kg}^{-1}$; T4 (negative control; NC): PC with a reduction in ME of $90 \mathrm{Kcal} \mathrm{kg}^{-1}$; T5: $\mathrm{NC}$ with inclusion of exogenous lipase (10 $\left.000 \mathrm{U} \mathrm{kg}^{-1}\right)$; T6: $\mathrm{NC}$ with inclusion of emulsifier $\left(250 \mathrm{~g} \mathrm{t}^{-1}\right)$; $\mathrm{T} 7$ : $\mathrm{NC}$ with the inclusion of lipase $\left(10000 \mathrm{U} \mathrm{kg}^{-1}\right)$ and an emulsifier $\left(250 \mathrm{~g} \mathrm{t}^{-1}\right)$.

The birds were fed corn and soybean meal diets, with use of phytase (1000 U kg-1) and reduction of 0.15 percentage points of calcium and available phosphorus, following a four-stage feeding programme: pre-starter ( 1 to 10 days), initial (11 to 21 days), growth I (22 to 31 days), and growth II (32 to 37 days).

The diets were formulated to have the same level of protein, vitamins, and minerals, adjusted according to the equations of nutritional requirements (lysine and its relation to other amino acids, as well as digestible essential nitrogen and other nutrients) suggested by Rostagno (2017), with variations in the metabolisable energy level according to the treatments evaluated. The commercial additives Linerzyme (100 $000 \mathrm{U} \mathrm{g}^{-1}$ lipase activity) and Lipidol Powder 50 (500 $\mathrm{g} \mathrm{kg}^{-1}$ soybean lecithin), when included in the feed, partially replaced inert material to obtain the respective treatments (Tables 1 and 2).

Performance characteristics (weight gain (WG), feed intake (FI), feed conversion (FC), and viability of rearing), carcass yield, cut (chest and leg) yield, and the relative weight of abdominal fat were determined. The digestibility of diets was evaluated by determination of the total dry matter apparent coefficient (CDADM), total ethereal extract apparent coefficient (CDAEE), gross metabolisable energy (CAMGE), and of the apparent metabolisable energy (AME). 
Table 1. Centesimal composition and calculated nutritional levels of experimental diets on the phases 1 to 21 days and 11 to 21 days age of birds fed ME levels and additivies to improve lipid digestion.

\begin{tabular}{|c|c|c|c|c|c|c|c|c|}
\hline \multirow{3}{*}{ Ingredients $(\%)$} & \multicolumn{4}{|c|}{ Phase 1 to 10 days } & \multicolumn{4}{|c|}{ Phase 11 to 21 days } \\
\hline & \multirow{2}{*}{$\mathrm{PC}$} & \multicolumn{3}{|c|}{ ME reduction $\left(\mathrm{Kcal} \mathrm{kg}^{-1}\right)$} & \multirow{2}{*}{$\mathrm{PC}$} & \multicolumn{3}{|c|}{ ME reduction $\left(\mathrm{Kcal} \mathrm{kg}^{-1}\right)$} \\
\hline & & PC-30 & PC-60 & PC-90 & & PC-30 & PC-60 & PC-90 \\
\hline Corn & 51.460 & 52.154 & 52.848 & 53.421 & 51.487 & 52.181 & 52.875 & 53.448 \\
\hline Soybean meal & 40.626 & 40.506 & 40.386 & 40.287 & 39.440 & 39.320 & 39.200 & 39.101 \\
\hline Soybean oil & 3.486 & 2.910 & 2.333 & 1.797 & 5.029 & 4.453 & 3.876 & 3.340 \\
\hline Dicalcium phosphate & 1.324 & 1.323 & 1.322 & 1.321 & 1.261 & 1.263 & 1.265 & 1.266 \\
\hline Limestone & 0.983 & 0.985 & 0.986 & 0.988 & 0.963 & 0.962 & 0.961 & 0.960 \\
\hline Methionine $\mathrm{MHA}^{1}$ & 0.534 & 0.533 & 0.533 & 0.532 & 0.454 & 0.453 & 0.452 & 0.451 \\
\hline Sulphate lysine $70 \%$ & 0.550 & 0.553 & 0.556 & 0.558 & 0.406 & 0.409 & 0.412 & 0.415 \\
\hline L-threonine 98\% & 0.178 & 0.178 & 0.178 & 0.178 & 0.122 & 0.122 & 0.122 & 0.122 \\
\hline Vitamin Premix ${ }^{2}$ & 0.100 & 0.100 & 0.100 & 0.100 & 0.100 & 0.100 & 0.100 & 0.100 \\
\hline Trace mineral premix ${ }^{3}$ & 0.050 & 0.050 & 0.050 & 0.050 & 0.050 & 0.050 & 0.050 & 0.050 \\
\hline Sodium Chloride & 0.533 & 0.533 & 0.533 & 0.533 & 0.519 & 0.519 & 0.519 & 0.518 \\
\hline Betaine 95\% & 0.045 & 0.045 & 0.045 & 0.045 & 0.039 & 0.039 & 0.039 & 0.039 \\
\hline Phytase $^{4}$ & 0.010 & 0.010 & 0.010 & 0.010 & 0.010 & 0.010 & 0.010 & 0.010 \\
\hline $\mathrm{BMD}^{5}$ & 0.050 & 0.050 & 0.050 & 0.050 & 0.050 & 0.050 & 0.050 & 0.050 \\
\hline Diclazuril & 0.020 & 0.020 & 0.020 & 0.020 & 0.020 & 0.020 & 0.020 & 0.020 \\
\hline Antioxidant & 0.010 & 0.010 & 0.010 & 0.010 & 0.010 & 0.010 & 0.010 & 0.010 \\
\hline Inert $^{6}$ & 0.040 & 0.040 & 0.040 & 0.100 & 0.040 & 0.040 & 0.040 & 0.100 \\
\hline Total & 100 & 100 & 100 & 100 & 100 & 100 & 100 & 100 \\
\hline \multicolumn{9}{|c|}{ Calculated Composition (\%) } \\
\hline $\mathrm{ME}\left(\mathrm{Kcal} \mathrm{kg}^{-1}\right)$ & 3,000 & 2,970 & 2,940 & 2,910 & 3,100 & 3,070 & 3,040 & 3,010 \\
\hline GE (Kcal kg-1) (Det.) & - & - & - & - & 4,136 & 4,102 & 4,083 & 4,068 \\
\hline Extract ethereal (Det.) & - & - & - & - & 8.750 & 7.650 & 7.484 & 6.915 \\
\hline Crude Protein & 23.24 & 23.24 & 23.24 & 23.24 & 22.53 & 22.53 & 22.53 & 22.53 \\
\hline $\mathrm{N}$ essential & 1.921 & 1.921 & 1.921 & 1.921 & 1.837 & 1.837 & 1.837 & 1.837 \\
\hline Lysine digestible & 1.430 & 1.430 & 1.430 & 1.430 & 1.321 & 1.321 & 1.321 & 1.321 \\
\hline Met + Cys. digestible & 1.058 & 1.058 & 1.058 & 1.058 & 0.977 & 0.977 & 0.977 & 0.977 \\
\hline Threonine digestible & 0.944 & 0.944 & 0.944 & 0.944 & 0.872 & 0.872 & 0.872 & 0.872 \\
\hline Calcium & 0.921 & 0.921 & 0.921 & 0.921 & 0.824 & 0.824 & 0.824 & 0.824 \\
\hline Avaiable Phosphorus & 0.353 & 0.353 & 0.353 & 0.353 & 0.284 & 0.284 & 0.284 & 0.284 \\
\hline Sodium & 0.225 & 0.225 & 0.225 & 0.225 & 0.219 & 0.219 & 0.219 & 0.219 \\
\hline
\end{tabular}

ME: Metabolizable energy. GE: Gross energy. N essential: Nitrogen dibestible essential.PC: Positive Control. Det: determined in natural matter basis.

*PC-90 treatment with major reduction of ME being considered Negative Control (NC)

${ }^{1}$ Methionine MHA 84\%: methionine hidroxy analogue. ${ }^{2}$ Vitamin Premix (Guarantee levels/kg premix): Vitamin A (mín): $9,000,000$ UI; Vitamin D3 (mín): 2,500,000 UI; Vitamin E (mín): 20,000 UI; Vitamin K3 (mín): 2,500 mg; Vitamin B1 (mín): 2,000 mg; Vitamin B2 (mín): 6,000mg; Pantothenic acid (mín): 12 g; Vitamin B6 (mín): 3,000 mg; Vitamin B12 (mín): 15,000 mcg; Nicotinic Acid (mín): 35 g; Folic Acid (mín): 1,500 mg; Biotin (mín): 100 mg; Selenium (mín): 250 mg. ${ }^{3}$ Trace mineral Premix (Guarantee levels/kg premix): Iron - Fe (mín): 100,00 $\mathrm{g} \mathrm{kg}^{-1}$; Copper - Cu (mín): 12,00 g kg-1; Zinc - Zn (mín): 120,00 g kg ; Manganese - Mn (mín): 120,00 $\mathrm{g} \mathrm{kg}^{-1}$; Iodine - I (mín): 2,500 mg kg-1. ${ }^{4}$ Phytase: $10000 \mathrm{U} \mathrm{g}^{-1}$.

${ }^{5}$ Bacitracin methylene disilicylate. ${ }^{6}$ Sand and/or additivies. ${ }^{7}$ Calculated composition based suggestted nutritional levels by Rostagno (2017). 
Table 2. Centesimal composition and calculated nutritional levels of experimental diets on the phases 22 to 31 days and 32 to 37 days age of birds ME levels and additivies to improve lipid digestion.

\begin{tabular}{|c|c|c|c|c|c|c|c|c|}
\hline \multirow{3}{*}{ Ingredientes (\%) } & \multicolumn{4}{|c|}{ Phase 22 to 31 days } & \multicolumn{4}{|c|}{ Phase 32 to 37 days } \\
\hline & \multirow{2}{*}{$\mathrm{PC}$} & \multicolumn{3}{|c|}{ ME reduction $\left(\mathrm{Kcal} \mathrm{kg}^{-1}\right)$} & \multirow{2}{*}{$\mathrm{PC}$} & \multicolumn{3}{|c|}{ ME reduction $\left(\mathrm{Kcal} \mathrm{kg}^{-1}\right)$} \\
\hline & & PC-30 & PC-60 & PC-90 & & PC-30 & PC-60 & PC-90 \\
\hline Corn & 52.938 & 53.632 & 54.326 & 54.899 & 54.586 & 55.281 & 55.975 & 56.547 \\
\hline Soybean meal & 38.103 & 37.983 & 37.863 & 37.764 & 36.717 & 36.597 & 36.477 & 36.378 \\
\hline Soybean oil & 6.058 & 5.481 & 4.904 & 4.368 & 6.453 & 5.876 & 5.299 & 4.763 \\
\hline Dicalcium phosphate & 0.599 & 0.598 & 0.597 & 0.596 & 0.322 & 0.321 & 0.320 & 0.319 \\
\hline Limestone & 0.762 & 0.764 & 0.766 & 0.767 & 0.682 & 0.683 & 0.685 & 0.686 \\
\hline Methionine MHA $^{1}$ & 0.377 & 0.377 & 0.376 & 0.375 & 0.301 & 0.300 & 0.299 & 0.299 \\
\hline Sulphate lysine $70 \%$ & 0.277 & 0.280 & 0.283 & 0.286 & 0.151 & 0.154 & 0.157 & 0.160 \\
\hline L-threonine 98\% & 0.070 & 0.070 & 0.070 & 0.069 & 0.018 & 0.017 & 0.017 & 0.017 \\
\hline Vitamin Premix ${ }^{2}$ & 0.100 & 0.100 & 0.100 & 0.100 & 0.100 & 0.100 & 0.100 & 0.100 \\
\hline Trace mineral premix ${ }^{3}$ & 0.050 & 0.050 & 0.050 & 0.050 & 0.050 & 0.050 & 0.050 & 0.050 \\
\hline Sodium Chloride & 0.504 & 0.504 & 0.504 & 0.504 & 0.484 & 0.484 & 0.484 & 0.484 \\
\hline Betaine $95 \%$ & 0.032 & 0.032 & 0.032 & 0.032 & 0.026 & 0.026 & 0.026 & 0.026 \\
\hline Phytase $^{4}$ & 0.010 & 0.010 & 0.010 & 0.010 & 0.010 & 0.010 & 0.010 & 0.010 \\
\hline $\mathrm{BMD}^{5}$ & 0.050 & 0.050 & 0.050 & 0.050 & 0.050 & 0.050 & 0.050 & 0.050 \\
\hline Diclazuril & 0.020 & 0.020 & 0.020 & 0.020 & - & - & - & - \\
\hline Antioxidant & 0.010 & 0.010 & 0.010 & 0.010 & 0.010 & 0.010 & 0.010 & 0.010 \\
\hline Inert $^{6}$ & 0.040 & 0.040 & 0.040 & 0.100 & 0.040 & 0.040 & 0.040 & 0.100 \\
\hline Total & 100 & 100 & 100 & 100 & 100 & 100 & 100 & 100 \\
\hline \multicolumn{9}{|c|}{ Calculated Composition $(\%)^{7}$} \\
\hline ME $\left(\mathrm{Kcal} \mathrm{kg}^{-1}\right)$ & 3,200 & 3,170 & 3,140 & 3,110 & 3,250 & 3,220 & 3,190 & 3,160 \\
\hline GE (Kcal kg-1) (Det.) & - & - & - & - & 4,249 & 4,217 & 4,207 & 4,171 \\
\hline Extract ethereal (Det.) & - & - & - & - & 9.075 & 8.450 & 8.223 & 7.444 \\
\hline Crude Protein & 21.88 & 21.88 & 21.88 & 21.88 & 21.22 & 21.22 & 21.22 & 21.22 \\
\hline $\mathrm{N}$ essential & 1.759 & 1.759 & 1.759 & 1.759 & 1.6810 & 1.6810 & 1.6810 & 1.6810 \\
\hline Lysine digestible & 1.219 & 1.219 & 1.219 & 1.219 & 1.118 & 1.118 & 1.118 & 1.118 \\
\hline Met + Cys. digestible & 0.902 & 0.902 & 0.902 & 0.902 & 0.827 & 0.827 & 0.827 & 0.827 \\
\hline Threonine digestible & 0.805 & 0.805 & 0.805 & 0.805 & 0.738 & 0.738 & 0.738 & 0.738 \\
\hline Calcium & 0.628 & 0.628 & 0.628 & 0.628 & 0.514 & 0.514 & 0.514 & 0.514 \\
\hline Avaiable Phosphorus & 0.215 & 0.215 & 0.215 & 0.215 & 0.162 & 0.162 & 0.162 & 0.162 \\
\hline Sodium & 0.213 & 0.213 & 0.213 & 0.213 & 0.205 & 0.205 & 0.205 & 0.205 \\
\hline
\end{tabular}

ME: Metabolizable energy. GE: Gross energy. N essential: Nitrogen dibestible essential. PC: Positive Control. Det: determined in natural matter basis.

*PC-90 treatment with major reduction of ME being considered Negative Control (NC)

${ }^{1}$ Methionine MHA 84\%: methionine hidroxy analogue. ${ }^{2}$ Vitamin Premix (Guarantee levels/kg premix): Vitamin A (mín): $9,000,000$ UI; Vitamin D3 (mín): 2,500,000 UI; Vitamin E (mín): 20,000 UI; Vitamin K3 (mín): 2,500 mg; Vitamin B1 (mín): 2,000 mg; Vitamin B2 (mín): 6,000mg; Pantothenic acid (mín): 12 g; Vitamin B6 (mín): 3,000 mg; Vitamin B12 (mín): 15,000 mcg; Nicotinic Acid (mín): 35 g; Folic Acid (mín): 1,500 mg; Biotin (mín): 100 mg; Selenium (mín): 250 mg. ${ }^{3}$ Trace mineral Premix (Guarantee levels/kg premix): Iron - Fe (mín): 100,00 g kg-1; Copper - Cu (mín): 12,00 g kg-1 Zinc - Zn (mín): 120,00 g kg-1; Manganese - Mn (mín): 120,00 $\mathrm{g} \mathrm{kg}^{-1}$; Iodine - I (mín): 2,500 mg kg-1. ${ }^{4}$ Phytase: $10000 \mathrm{U} \mathrm{g}^{-1}$.

${ }^{5}$ Bacitracin methylene disilicylate. ${ }^{6}$ Sand and/or additivies. ${ }^{7}$ Calculated composition based suggestted nutritional levels by Rostagno (2017). 
At 37 days, one bird per pen with the closest weight to the mean of the experimental unit (maximum variation of $2 \%$ ) was fed for $5 \mathrm{~h}$ and then weighed and slaughtered for measurements of the carcass yield (\%), cut (breast and legs) yields $(\%)$, and weight of abdominal fat.

Two metabolism assays were performed in parallel to the performance experiment at different periods of the broiler breeding cycle. The first trial was carried out in the 11 to 21 days phase, and consisted of five days of adaptation and five days of collection, according to the guidelines proposed by Ferreira and Nascimento (2016). The second trial was performed during the interval of 31 to 37 days, and consisted of three days of adaptation and four days of collection of excreta, as suggested by Avila et al. (2006). The birds with an individual weight close to the mean weight of their experimental unit $( \pm 3 \%)$ were selected from the performance experiment and distributed five per cage for the first trial and two per cage for the second trial.

The laboratory analyses were carried out in the bromatology laboratory of the Federal University of Recôncavo da Bahia. The excreta samples were homogenised, aliquots of $300 \mathrm{~g}$ were removed and air-dired in ventilated oven at $55{ }^{\circ} \mathrm{C}$ for $72 \mathrm{~h}$, and then excreta and feed samples were ground in a $16 \mathrm{~mm}$ mesh sieve with $1 \mathrm{~mm}$ sieves for further analysis as described by Ferreira and Nascimento (2016).

The diets were the same as those used for the performance experiment, formulated to meet the requirements of each stage, with the use of chromium oxide ( $5 \mathrm{~g} \mathrm{~kg}^{-1}$ of feed) as an indicator of indigestibility. The excreta and the diets were analysed for each experimental unit, and the values of dry matter, ethereal extract, and crude energy were determined.

The level of chromium was analysed by atomic absorption spectrophotometry (MP-AES 4200 Agilent - Agilent Technologies - USA), the crude energy content was determined by measuring the heat of combustion of the samples with the aid of a calorimetric pump (IKA C 200 - IKA Works - Germany), and the ethereal extract was analysed using the Goldfish method. The apparent digestibility of the nutrients was determined as proposed by Sakomura and Rostagno (2016) by using the concentration of chromium oxide in the diet and excreta.

The experimental data were submitted to statistical analysis using the statistical package SAS. The mean values of the nutritional plans were compared by means of an SNK test and the following orthogonal contrasts: contrast $1(\mathrm{CP} \times$ energy reduction): $\mathrm{T} 1$ vs $\mathrm{T} 2+\mathrm{T} 3+\mathrm{T} 4$; contrast 2 (CP $\times$ additives): $\mathrm{T} 1$ vs $\mathrm{T} 5+\mathrm{T} 6+\mathrm{T} 7$; contrast $3(\mathrm{CN}$ $\times$ additives): $\mathrm{T} 4$ vs T $5+\mathrm{T} 6+\mathrm{T} 7$; contrast 4 (lipase $\times$ emulsifier): T5 vs T6; contrast 5 (lipase $\times$ lipase + emulsifier): T5 vs T7; and contrast 6 (emulsifier $\times$ lipase + emulsifier): T6 vs T7. A significance value of 0.05 was considered for all analyses.

\section{Results and Discussion}

During the experimental period, the mean values of the temperature and humidity index (UTI) calculated were 77.3, 78.0, 78.6, 78.2, and 77.6 for phases 1 to 10,11 to 21,22 to 31 , and 32 to 37 days, respectively. The ITU range considered ideal for broiler production, according to Silva et al. (2004), ranges from 72.4 to 80.0 (first week), 68.4 to 76.0 (second week), 64.5 to 72.0 (third week), 60.5 to 68.0 (fourth week), 56.6 to 64.0 (fifth week), and 56.6 to 60.0 (sixth week of age), therefore, based on these values and the calculated UTI results for the present study, one can conclude that the broiler chickens were subjected to conditions of heat stress in the last weeks of rearing, which probably compromised the welfare and performance of the birds.

The coefficient of apparent dry matter digestibility (CDADM) and gross metabolisable 
energy coefficient (CMAGE) were not influenced $(\mathrm{P}>0.05)$ by the reduction in ME levels or by lipase and/or emulsifier supplementation in the phases evaluated (Table 3).

In the initial phase (11-21 days), a higher ( $\mathrm{P}$ $<0.05$ ) coefficient of apparent digestibility of ethereal extract and AME value was observed in chickens fed with diets without an ME reduction (PC) than those fed diets with an energy reduction $(\mathrm{T} 1 \times \mathrm{T} 2+\mathrm{T} 3+\mathrm{T} 4)$ or those fed a reduced energy diet and supplemented with lipase and/or emulsifier $(\mathrm{T} 1 \times \mathrm{T} 5+\mathrm{T} 6+\mathrm{T} 7)$. In contrast, birds fed with reduced energy diets supplemented with lipase and emulsifier showed a lower CDAEE and AME (dry matter basis) than PC group.

The determined values of AME for 11-21 days were highest for the PC groups and the group with a reduction of only $30 \mathrm{Kcal}$. The PC group presented a value approximately $85 \mathrm{Kcal}$ more than the groups with inclusion of additives to improve lipids digestion $(\mathrm{T} 1 \times \mathrm{T} 5+\mathrm{T} 6+\mathrm{T} 7)$.

No effect $(\mathrm{P}>0.05)$ of the treatments on CDADM, CDAEE, or CMAGE was observed in the growth phase II (31-37 days). However, the determined values of AME were different $(\mathrm{P}<0.05)$ between the groups evaluated.

In this phase (31-37 days), the isolated supplementation of emulsifier generated an AME value of $51 \mathrm{Kcal} \mathrm{kg}^{-1}$ more than the group of birds receiving the $\mathrm{NC}$ diet, and was also higher (by $42 \mathrm{Kcal})$ than the value determined for the group supplemented with lipase alone. It was also observed that the group of birds fed diets with a reduction of $60 \mathrm{Kcal}$ (T3) had a highest AME value $(\mathrm{P}<0.05)$.

The PC group presented a highest CDAEE in the 11-21 day phase and these results are in agreement with those observed by Park et al. (2017), who verified the reduced digestibility of ethereal extract in rations with lower levels of metabolisable energy for broilers. However, the age of the birds was 35 days, whereas in the current study, at that stage, no effects of the different energy levels were detected on lipid digestion. Hu et al. (2018) observed increased digestibility of ethereal extracts in the reduced energy diets of 28-day-old broilers. Such variations in responses suggest the need for further research to elucidate how lipid digestibility is influenced by energy levels, the inclusion of lipids, the age of the birds, or the degree of development of the digestive tract.

Based on the digestibility results in the period from 11 to 21 days, comparison of the treatments that used additives in addition to the low energy level (NC) treatment indicates, as suggested by Zampiga et al. (2016), that the use of a lipaseassociated emulsifier might not have an effect on the digestibility coefficients of diets with reduced levels of metabolisable energy. According to the author, the digestibility of ethereal extract might be related to factors such as the type of lipid used in the diet, and the most evident results were observed for diets that used fat as the main lipid source. Similarly, Slominski et al. (2006) found no effect on the digestibility of nutrients when exogenous lipase was added to broiler feeds in the initial phase, therefore, the inclusion of lipase to improve energy utilisation by birds should be reconsidered.

These results confirm the report by Zhang et al. (2011) that the use of an emulsifier in diets aids digestibility, facilitating the action of lipase, favouring the formation of micelles of lipolysis products, and potentiating absorption by the intestinal mucosa. In addition, it increases the formation of protein channels and the permeability of the cell membrane (ZAMPIGA et al., 2016). 


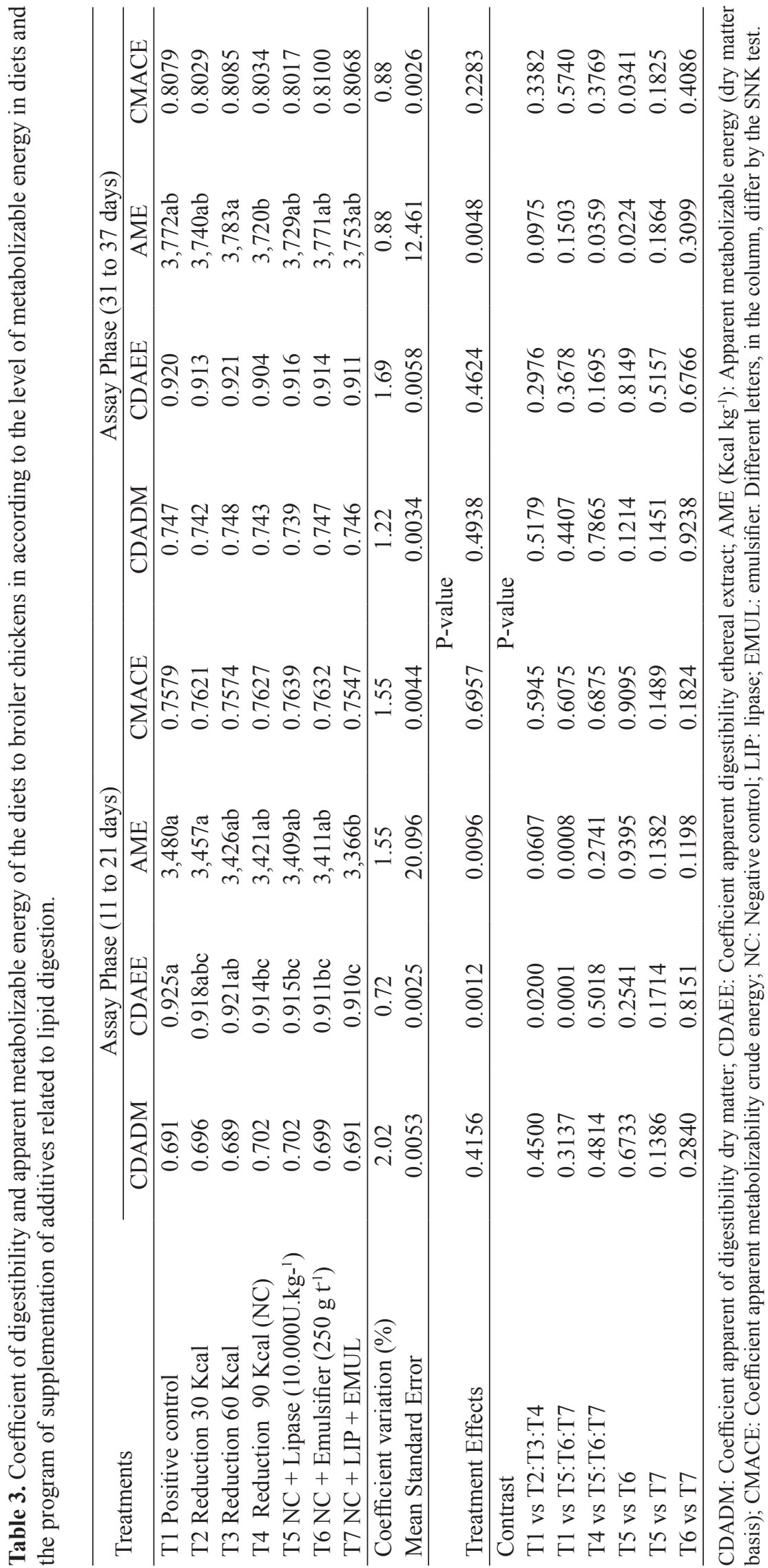


However, Zaefarian et al. (2015) reported that the increase in lipid digestibility with the use of an emulsifier in broiler feed during the initial phase might not be sufficient to increase the use of the apparent metabolisable energy and, in addition, the lack of an effect on digestibility is related to the short duration of the study, which might not reflect the performance of the birds. A similar result was observed in the present experiment, where the use of emulsifier was more effective in the final phase.

Park et al. (2017) observed improved energy utilisation and digestibility of ethereal extract when higher emulsifier inclusions $(0.030 \%, 0.060 \%$, and $0.090 \%$ ) were used in broiler feeds, which might suggest that the level of inclusion used in the present study $(0.025 \%)$ was insufficient to promote the effect of the emulsifier alone on the digestibility of dry matter, ethereal extract, and gross energy in the initial phase.

The growth phase II (31-37) was the phase that clearly had a higher concentration of substrate for the action of lipase and emulsifier. However, there were no effects of the additives evaluated on the CDAEE, in contrast, the emulsifier resulted in a higher value of AME than that of the NC group, which was not observed with the inclusion of lipase alone. This might indicate that although the exogenous lipase could, in principle, circumvent the limitation of endogenous lipase synthesis to optimise digestion, the emulsifier could have a direct effect on energy utilisation by improving lipid utilisation. In agreement with the results obtained, Zhao and Kim et al. (2017) showed no effect on digestibility (dry matter and ethereal extract) of the inclusion of emulsifier in feed in the final stage of broiler rearing.
The performance variables $\mathrm{FI}, \mathrm{WG}$, and $\mathrm{FC}$ were influenced $(\mathrm{P}<0.05)$ by the reduced levels of metabolisable energy and/or the use of additives related to lipid digestion throughout the experiment (table 4).

Comparison of the PC group with the groups that had reductions in metabolisable energy (reduction of 30,60 , and $90 \mathrm{Kcal} \mathrm{kg}^{-1}$ ) without the inclusion of additives showed no difference $(\mathrm{P}>0.05)$ in FI at 21 days and up to 37 days of age (global creation period). However, WG and FC differed $(\mathrm{P}<0.05)$ between these evaluated treatments, and the ration without a reduction in energy levels (PC) produced a highest WG and best FC of the birds.

In the initial phase, the $\mathrm{WG}$ of the birds presented significant variation $(\mathrm{P}<0.05)$ when the $\mathrm{PC}$ was compared to the groups supplemented with additives $(\mathrm{T} 1 \times \mathrm{T} 5+\mathrm{T} 6+\mathrm{T} 7)$. The inclusion of additives resulted in a lower WG, however, the FC did not differ between the groups.

The group fed a diet with a low energy level (NC) presented a lower FI and worse FC than the groups supplemented with additives to improve lipid utilisation $(\mathrm{T} 4 \times \mathrm{T} 5+\mathrm{T} 6+\mathrm{T} 7)$.

The use of lipase resulted in a higher WG $(\mathrm{P}$ $<0.05$ ), sustained by a higher feed consumption, than the group supplemented with emulsifier alone $($ T5 $\times$ T6). Similarly, the use of lipase resulted in a higher WG and higher FI than the inclusion of lipase and emulsifier together in diets $(\mathrm{T} 5 \times \mathrm{T} 7)$.

No effect $(\mathrm{P}>0.05)$ was observed of the use of emulsifier alone compared to its use in conjunction with lipase $(\mathrm{T} 6 \times \mathrm{T} 7)$ for any of the performance characteristics during the broiler rearing cycle. 
Table 4. Performance of broilers during the period from 1 to 21 and 1 to 37 days, according to the level of metabolizable energy in diets and the program of supplementation of additives related to lipid digestion.

\begin{tabular}{|c|c|c|c|c|c|c|c|}
\hline \multirow[t]{2}{*}{ Treatments } & \multicolumn{3}{|c|}{1 to 21 days } & \multicolumn{4}{|c|}{1 to 37 days } \\
\hline & FI (kg) & WG $(\mathrm{kg})$ & FC & FI (kg) & WG $(\mathrm{kg})$ & $\mathrm{FC}$ & LV (\%) \\
\hline T1 Positive control & $1.173 \mathrm{a}$ & $0.982 \mathrm{a}$ & $1.195 \mathrm{~b}$ & $3.581 \mathrm{bc}$ & $2.500 \mathrm{a}$ & $1.433 \mathrm{c}$ & 95.4 \\
\hline T2 Reduction 30 Kcal & $1.160 \mathrm{ab}$ & $0.970 \mathrm{ab}$ & $1.196 \mathrm{ab}$ & $3.580 \mathrm{bc}$ & $2.467 \mathrm{a}$ & $1.451 \mathrm{bc}$ & 95.2 \\
\hline T3 Reduction 60 Kcal & $1.172 \mathrm{a}$ & $0.965 \mathrm{ab}$ & $1.215 \mathrm{ab}$ & $3.562 \mathrm{c}$ & $2.456 \mathrm{a}$ & $1.450 \mathrm{bc}$ & 94.2 \\
\hline T4 Reduction $90 \mathrm{Kcal}(\mathrm{NC})$ & $1.179 \mathrm{a}$ & $0.958 \mathrm{ab}$ & $1.232 \mathrm{a}$ & $3.571 \mathrm{c}$ & $2.411 b$ & $1.481 \mathrm{a}$ & 95.4 \\
\hline T5 NC + Lipase (10.000U.kg-1) & $1.184 \mathrm{a}$ & $0.982 \mathrm{a}$ & $1.205 \mathrm{ab}$ & $3.642 \mathrm{a}$ & $2.484 \mathrm{a}$ & $1.466 \mathrm{ab}$ & 92.4 \\
\hline T6 NC + Emulsifier $\left(250 \mathrm{~g} \mathrm{t}^{-1}\right)$ & $1.155 \mathrm{ab}$ & $0.953 b$ & $1.212 \mathrm{ab}$ & $3.622 \mathrm{ab}$ & $2.483 \mathrm{a}$ & $1.459 \mathrm{~b}$ & 95.7 \\
\hline T7 NC + LIP + EMUL & $1.141 \mathrm{~b}$ & $0.947 \mathrm{~b}$ & $1.204 \mathrm{ab}$ & $3.588 \mathrm{bc}$ & $2.487 \mathrm{a}$ & $1.443 \mathrm{bc}$ & 93.0 \\
\hline Coefficient variation (\%) & 1.71 & 1.81 & 1.50 & 0.94 & 1.25 & 1.09 & 3.13 \\
\hline Mean Standard Error & 0.0075 & 0.0066 & 0.0068 & 0.0127 & 0.0116 & 0.0060 & 1.1156 \\
\hline Treatment Effects & 0.003 & 0.002 & 0.009 & $\begin{array}{r}\text { P-value } \\
<0.001\end{array}$ & $<0.001$ & $<0.001$ & 0.2517 \\
\hline Contrast & & & & $\mathrm{P}$-value & & & \\
\hline T1 vs T2:T3:T4 & 0.744 & 0.027 & 0.022 & 0.521 & $<0.001$ & $<0.001$ & 0.720 \\
\hline T1 vs T5:T6:T7 & 0.128 & 0.009 & 0.136 & 0.016 & 0.263 & 0.002 & 0.192 \\
\hline T4 vs T5:T6:T7 & 0.030 & 0.688 & 0.004 & 0.003 & $<0.001$ & $<0.001$ & 0.189 \\
\hline T5 vs T6 & 0.010 & 0.003 & 0.465 & 0.271 & 0.923 & 0.411 & 0.067 \\
\hline T5 vs T7 & 0.000 & 0.001 & 0.936 & 0.004 & 0.875 & 0.009 & 0.737 \\
\hline T6 vs T7 & 0.192 & 0.538 & 0.418 & 0.064 & 0.799 & 0.061 & 0.095 \\
\hline
\end{tabular}

FI: Feed intake WG: weight gain; FC: feed conversion; LV: liviability; NC: negative control; LIP: lipase; EMUL: emulsifier. Different letters, in the column, differ by the SNK test.

At 37 days, it was observed that the reduction in $\mathrm{ME}$ of $90 \mathrm{Kcal} \mathrm{kg}^{-1}(\mathrm{NC})$ resulted in a lower FI and WG and worse $(\mathrm{P}<0.05) \mathrm{FC}$ of the birds than the $\mathrm{PC}$ group. The $\mathrm{PC}$ group showed the best $(\mathrm{P}<0.05)$ FC among all the evaluated treatments.

The use of lipase or an emulsifier alone resulted in a higher $(\mathrm{P}<0.05) \mathrm{FI}$ of the birds with a consequent increase in $\mathrm{WG}$, which was comparable to the PC group. However, the FC of the birds in those groups was worse than the birds fed a diet without any reduction in ME (PC). The use of lipase and emulsifier together improved the birds' FC in the order of $1.57 \%$ and $2.57 \%$ compared to the lipase group alone and to the $\mathrm{NC}$ group, respectively. The breeding viability was not influenced $(\mathrm{P}>0.05)$ by any of the evaluated treatments.

The evaluation of the performance results at 21 days of age, considering that the experimental diets were formulated to have same nutritional composition and the lack of variation in FI as a function of the energy level, indicates that the birds ingested similar amounts of nutrients, however, the higher WG by the PC group, in addition to the improvement in FC, might be associated with the higher consumption of metabolisable energy (CME), and the values determined in the metabolic assay for this phase confirm a higher ME value.

The positive effect of the higher energy level on FC observed in the present study might be related to a possible improvement in digestibility (as observed for CDAEE and AME), nutrient uptake, and a net energy increase of the diet (due to lower caloric metabolic during digestion, absorption and nutrient metabolism), as a result of a higher level of lipid inclusion providing energy in the diet, in addition to the reduction of the fine particles (powder) in the ration, as suggested by Duarte et al. (2010).

According to Richards and Proszkowiec-Weglarz (2007) and Roll et al. (2011), although chickens adjust feed intake to meet their energy needs, this 
adjustment is limited in modern broiler chickens, which have been selected for rapid growth and to consume ration as a function of the physical capacity of the gastrointestinal tract, leading to hyperphagia behaviour as result of genetic improvements.

The results observed for WG and FC corroborate those obtained by Savoldi et al. (2012), who reported the highest weight gain and best feed conversion for birds fed with feed containing the highest levels of energy out of the different levels of metabolisable energy evaluated (2700, 2825, 2950, and $3075 \mathrm{Kcal}$ $\mathrm{kg}^{-1}$ ) for broiler chickens during the initial phase.

The improvement in FC in response to increased energy levels corroborates the results obtained by Dozier et al. (2011) and Zhao and Kim. (2017). A similar result was found by Infante-Rodríguez et al. (2016) when evaluating rations with increasing levels of metabolisable energy in the 1 to 21-day phase $\left(2960,3000,3040\right.$, and $3080 \mathrm{Kcal} \mathrm{kg}^{-1}$ of feed) who verified a better FC for broilers fed the diets containing the highest energy levels.

In the initial phase, probably a higher feed intake and consequent higher CME in birds of the lipasesupplemented feed group might have been the reason for the higher weight gain than that of the group of birds given rations containing only emulsifier or emulsifier in combination with a lipase. The results indicate (based on FC) that the use of lipase and an emulsifier, alone or in combination, had a beneficial effect on performance that supported a reduction of between 60 and $90 \mathrm{Kcal}$ in ME.

Concomitant lipase and emulsifier supplementation resulted in lower FI, WG, CDAEE, and AME values in the initial phase than the values obtained for birds given the same nutritional base (NC) without supplementation, which might indicate some conflict in the intestinal forms of action. Such facts have not yet been reported in the scientific literature, and thus possible explanations remain to be elucidated in future studies. Despite these findings, the observed values of FC indicate that there was a beneficial effect of the use, without, however, indicating additivity or synergy of the effects.

Considering the integral period evaluated (37 days), similar to the present experiment, InfanteRodríguez et al. (2016) verified an improvement in the FC of birds fed with higher energy rations. In agreement, Nogueira et al. (2013) observed an increase in weight gain and an improvement in feed conversion by birds in response to increased feed energy levels. In turn, Ferreira et al. (2015) reported a worse feed conversion rate of broiler chickens at 42 days of age in response to reduced feed metabolisable energy.

The results show that a decrease in energy levels during the growing cycle negatively affected weight gain and the feed conversion of broilers, possibly due to a lower CME. In the same way, Boontiam et al. (2016), when evaluating two metabolisable energy programmes (mean: 2875, 3000, and 3050 and high: 3025,3150 , and $3200 \mathrm{Kcal} \mathrm{kg-}$ , for phases 1 to 7,8 to 21 , and 22 to 35 days, respectively) reported lower weight gain at the end of the growing cycle in birds fed diets containing the lowest levels of metabolisable energy. These results also suggest that modern broiler chickens are less efficient at regulating feed intake according to the metabolisable energy level with increasing age.

Similarly, Maertens et al. (2015) observed an increase in weight gain on broiler chickens when using an emulsifier in a diet with a reduced metabolisable energy level $\left(100 \mathrm{Kcal} \mathrm{kg}^{-1}\right)$, however, without completely restoring weight gain to the level of the group without reduction. The results obtained in the present study suggest synergism in the use of lipase and emulsifier at the end of the growing cycle, however, such synergism seems to be influenced by the age of the birds, since in the overall phase, the response was more evident than in the initial phase, especially for FC.

The results for the use of the additives indicate, as suggested by Barbosa et al. (2012) and Wang et al. (2016), that the use of an emulsifier and lipase have 
a more evident beneficial effect on the performance of broiler chickens in diets with a reduced level of metabolisable energy than diets with energy and nutritional levels attended (on-top concept), thus improving the energy efficiency of the diet (higher net energy) and consequently improving the characteristics of performance of the broilers at the end of the growing cycle.

In addition to being able to improve energy utilisation and nutrient digestibility, the inclusion of exogenous enzymes in poultry diets might reduce the synthesis of endogenous enzymes, and consequently the organism would have a higher amount of amino acids for tissue synthesis (Barbosa et al., 2014) and a higher availability of net energy for growth, which would explain the improvement in the performance of the birds fed with the feed containing additives (lipase and lipase + emulsifier).

Corroborating the viability results, Kamran et al. (2008) did not observe variation in the viability of broilers at the end of the breeding cycle in response to the level of metabolisable energy of the ration. Similarly, Guerreiro Neto et al. (2011) found that the use of emulsifiers in broiler rations did not influence the viability of rearing broilers, regardless of the sources of metabolisable energy used. In agreement with this, Nagargoje et al. (2016) also did not observe an influence of this additive on the viability of broilers.

Despite nearly being significant for breast yield $(\mathrm{P}=0.077)$, the carcass traits, cuts, and biometrics of intestinal organs were not influenced by any of the treatments evaluated (Table 5).

Regarding the carcass yield of the birds at the end of the growing cycle, Gopinger et al. (2017), when evaluating variation in the energy level (variation \pm $200 \mathrm{Kcal} \mathrm{kg}^{-1}$ of metabolisable energy), also did not observe an effect of the energy level on the weight of the carcass or the cuts of the chickens at the end of the production cycle of the birds.

The absolute weight and yield of the carcass and the cuts (chest and thigh + overcoat) verified in the present study did not reflect the higher growth of the birds provided by the higher level of energy in the ration. Similarly, Nagata et al. (2011) reported the lack of an effect of the energy level of the ration on the relative weight of the breast and leg of broilers at 42 days of age.

For these same characteristics, when the additives were used, Nagargoje et al. (2016) did not observe variations in the relative weight of the cuts when comparing the groups of broilers fed diets containing lipase (10 $\left.000 \mathrm{IU} \mathrm{kg}^{-1}\right)$ to the control group at the end of the period from 1 to 42 days. Guerreiro Neto et al. (2011) also did not verify a variation in the carcass yield and cuts of the chickens that received rations supplemented with emulsifiers at 42 days of age.

The results obtained for absolute and relative abdominal fat do not confirm the reports of Meza et al. (2015), who observed a higher weight of abdominal fat and a higher rate of fat deposition in the carcass of broilers fed rations with higher levels of metabolisable energy at the end of the growth cycle.

Considering that birds experienced periods of heat stress, especially after the third week of life, the effect of the energy level on abdominal fat deposition might be related to the increase in the energy requirement to dissipate the birds' body heat, as suggested by Reyes et al. (2012). Therefore, the extra energy ingested by birds would be used to activate the mechanisms of heat loss and maintenance of body temperature, with no excess energy for the deposition as adipose tissue. However, our results are in agreement with those of Guerreiro Neto et al. (2011) and Cho et al. (2012), who did not verify an influence of the use of emulsifiers on the deposition of fat in the abdominal region of the birds.

The biometry of the organs corroborate the findings of Aziz et al. (2011), who did not observe an effect of rations with different metabolisable energy patterns $\left(2764,2921\right.$, and $2968 \mathrm{Kcal} \mathrm{kg}^{-1}$ and 2910, 3075, and $3125 \mathrm{Kcal} \mathrm{kg}^{-1}$ for the pre-initial, 
growth, and slaughter phases, respectively) on the liver and pancreas of broilers at 42 days of age.

According to Martins et al. (2015), the presence of higher levels of energy and nutrients might stimulate increased secretion of digestive enzymes, promoted by secretory cell hypertrophy, which results in increased development and, consequently, a higher relative weight of the organ. Thus, based on the previous studies and the results obtained in the present study, variations in metabolisable energy levels were likely not sufficient to produce an increase in the metabolic and/or enzymatic activity that would result in more development of the liver and pancreas.

Table 5. Carcass characteristics and organs development of the broilers chickens at the 37 days according to the level of metabolizable energy in diets and the program of supplementation of additives related to lipid digestion.

\begin{tabular}{|c|c|c|c|c|c|c|c|c|}
\hline \multirow[b]{2}{*}{ Treatments } & \multicolumn{4}{|c|}{ Yield/Relative weight $(\%)$} & \multicolumn{4}{|c|}{ Organs } \\
\hline & Carcass & Breast & Legs & FA & $\begin{array}{c}\text { Liver } \\
(\%)\end{array}$ & $\begin{array}{c}\text { Pancreas } \\
(\%)\end{array}$ & $\begin{array}{c}\text { SI } \\
(\%)\end{array}$ & $\begin{array}{c}\mathrm{LI} \\
\left(\mathrm{cm} \mathrm{kg}^{-1}\right)\end{array}$ \\
\hline T1 Positive control & 77.46 & 34.41 & 28.51 & 1.01 & 1.918 & 0.172 & 1.990 & 65.94 \\
\hline T2 Reduction $30 \mathrm{Kcal}$ & 77.65 & 34.93 & 28.48 & 0.75 & 1.886 & 0.172 & 1.942 & 67.25 \\
\hline T3 Reduction 60 Kcal & 76.41 & 34.77 & 28.32 & 0.76 & 1.835 & 0.170 & 1.996 & 65.07 \\
\hline T4 Reduction 90 Kcal (NC) & 77.39 & 34.22 & 28.51 & 0.74 & 1.858 & 0.179 & 1.902 & 65.81 \\
\hline T5 NC + Lipase (10.000U. $\left.\mathrm{kg}^{-1}\right)$ & 77.36 & 36.95 & 27.49 & 0.76 & 1.803 & 0.178 & 1.939 & 69.57 \\
\hline T6 NC + Emulsifier $\left(250 \mathrm{~g} \mathrm{t}^{-1}\right)$ & 78.18 & 36.10 & 27.93 & 0.85 & 1.741 & 0.161 & 1.972 & 65.99 \\
\hline Coefficient variation $(\%)$ & 1.53 & 5.11 & 4.85 & 23.22 & 10.93 & 14.62 & 15.15 & 9.16 \\
\hline Mean Standard Error & 0.4465 & 0.6811 & 0.5185 & 0.0714 & 0.7663 & 0.0095 & 0.1124 & 2.302 \\
\hline & \multicolumn{8}{|c|}{ P-value } \\
\hline Treatment Effects & 0.240 & 0.077 & 0.657 & 0.125 & 0.552 & 0.879 & 0.996 & 0.858 \\
\hline
\end{tabular}

Legs: thigh + overcoat. FA: fat abdominal; NC: Negative control; LIP: lipase; EMUL: emulsificante.SI: Small intestine; LI: length intestine.

The results for the absolute and relative weight of the bird organs in response to the use of the additives were similar to those observed by Abbas et al. (2016), who investigated the use of emulsifier in diets with different fat inclusions and did not observe an effect of the additives on liver weight at the end of the growing cycle.

However, the data of the present study are not in agreement with those of Raju et al. (2011) and Boontiam et al. (2016), who observed an increase in pancreatic weight when birds were fed with exogenous emulsifier, and the increase in relative body weight, according to the authors, might be indicative of increased digestion and lipid absorption.

\section{Conclusion}

The use of lipase alone $\left(10000 \mathrm{U} \mathrm{kg}^{-1}\right)$ influenced the feed intake of the birds and its supplementation in the diet was most effective in the initial phase, whereas the use of an emulsifier increased the metabolisable energy during the growth phase and was most effective in the final phase of creation.

The use of lipase associated with an emulsifier in reduced energy diets improves the performance of the birds without, however, improving the lipid digestibility in the evaluated phases. Reductions in the level of metabolisable energy of $90 \mathrm{Kcal} \mathrm{kg}^{-1}$ of the diet compromised the performance of broiler chickens. 
Reducing the metabolisable energy level, with or without lipase and emulsifier supplementation, does not interfere with the carcass yield and cuts of the broilers or influence the development of digestive tract organs.

All procedures performed in this study followed the legislation and standards in force with a protocol duly approved by CEUA (Ethics Committee on the Use of Animals/UFRB), under the registration number 23007027271 / 2017-02.

\section{References}

ABBAS, M. T.; ARIF. M.; SAEED, M., REYAD-ULFERDOUS, M.; HASSAN, M. A.; ARAIN, L. M.A.; REHMAN, A. Emulsifier effect on fat utilization in broiler chicken. Asian Journal of Animal and Veterinary, New York, v. 11, n. 3, p. 158-167, 2016. DOI: 10.3923/ ajava.2016.158.167

AVILA, V. S.; PAULA, A.; BRUM, P. A. R.; COLDEBELlA, A.; MAIER, J. C. Determinação do período de coleta total de excretas para estimativa dos valores de energia metabolizável em frangos de corte. Revista Brasileira de Zootecnia, Viçosa, v. 35, n. 5, p. 19661970, 2006. DOI: 10.1590/S151635982006000700012

AZIZ, B.; SADEGHI, G.; KARIMI, A.; ABED, F. Effects of dietary energy and protein dilution and time of feed replacement from starter to grower on broiler chickens performance. Journal of Central European Agriculture, Zagreb, v. 12, n. 1, p. 44-52, 2011. DOI: 10.5513/JCEA01/12.1.879

BARBOSA, N. A. A.; BONATO, M. A.; SAKOMURA, N. K.; DOURADO, L. R. B.; FERNANDES, J. B. K.; KAWAUCHI, I. M Digestibilidade ileal de frangos de corte alimentados com dietas suplementadas com enzimas exógenas. Comunicata Scientiae, Teresina, v. 5 , n. 4, p. 361-369, 2014. DOI: $10.14295 /$ cs.v5i4.460

BARBOSA, N.A.A.; SAKOMURA, N. K.; BONATO, M. A.; HAUSCHILD, L.; OVIEDO-RONDON, E. Enzimas exógenas em dietas de frangos de corte: desempenho. Ciência Rural, Santa Maria, v. 42, n. 8, p. 1497-1502, 2012. DOI: $10.1590 / \mathrm{S} 0103-84782012000800027$

BOONTIAM, W.; JUNG, B.; KIM, Y. Y. Effects of lysophospholipid supplementation to lower nutrient diets on growth performance, intestinal morphology, and blood metabolites in broiler chickens. Poultry Science, Savoyv, v. 96, n. 3, p. 593-601, 2016. DOI: 10.3382/ps/ pew269
CHO, J. H.; ZHAO, P.; KIM, I. H. Effects of emulsifier and multi-enzyme in different energy densitydiet on growth performance, blood profiles, and relative organ weight in broiler chickens. Journal of Agricultural Science, Cambridge, v. 4, n. 10, p. 161-168, 2012. DOI: 10.5539/jas.v4n10p161

DOZIER, W. A.; GEHRING, C. K.; CORZO, A.; OLANREWAJU, H. A. Apparent metabolizable energy needs of male and female broilers from 36 to 47 days of age. Poultry Science, Savoy, v. 90, n. 4, p.804-814, 2011. DOI: $10.3382 /$ ps.2010-01132

DUARTE, F. D.; LARA, L. J. C.; BAIÃO, N. C.; CANÇADO, S. V.; TEIXEIRA, J. L. Efeito da inclusão de diferentes fontes lipídicas em dietas para frangos de corte sobre o desempenho, rendimento e composição da carcaça. Arquivo Brasileiro de Medicina Veterinária e Zootecnia, Belo Horizonte, v. 62, n. 2, p. 439-444, 2010. DOI: 10.1590/S0102-09352010000200025

FERREIRA, G. S.; PINTO, M. F.; GARCIA NETO, M.; PONSANO, E. H. G.; GONÇALVES, C. A.; BOSSOLANI, I. L. C.; PEREIRA, A. G. Ajuste preciso do nível de energia na dieta de frangos de corte para controle do desempenho e da composição lipídica da carne. Ciência Rural, Santa Maria, v. 45, n. 1, p. 104-110, 2015. DOI: $10.1590 / 0103-8478$ cr20130206

FERREIRA, N. T.; NASCIMENTO, T. M. T. Metodologias para avaliar o conteúdo de energia dos alimentos. In. SAKOMURA, N. K.; ROSTAGNO, H. S. Métodos de pesquisa em nutrição de monogástricos. 2. ed. Jaboticabal: Funep, 2016. p. 31-66.

GOPINGER, E.; KRABBE, E. L.; SUREK, D.; LOPES, L. S.; AVILA, V. S. Live performance, carcass, and bone quality responses of grower and finisher broilers to dietary metabolizable energy levels. Brazilian Journal of Poultry Science. Campinas, v. 19, n. 4, p. 559-566, 2017. DOI: 10.1590/1806-9061-2017-0508

GUERREIRO NETO, A. C.; PEZZATO, A. C.; SARTORI, J. R.; MORI, C.; CRUZ, V. C.; FASCINA, V. B.; PINHEIRO, D. F.; MADEIRA, L. A.; GONÇALVES, J. C. Emulsifier in broiler diets containing different fat sources. Brazilian Journal of Poultry Science, Campinas, v. 13, n. 2, p. 119-125, 2011. DOI: 10.1590/S1516$635 \times 2011000200006$

HU, Y. D.; LAN, D.; ZHU, Y.; PANG, H. Z.; MU, X. P.; HU, X. F. Efect of diets with diferent energy and lipase levels on performance, digestibility and carcass trait in broilers. Asian-Australasian Journal of Animal Sciences, Seoul, v. 31, n. 8, p. 1275-1284, 2018. DOI: 10.5713/ ajas. 17.0755

INFANTE-RODRÍGUEZ, F.; SALINAS-CHAVIRA, J.; 
MONTAÑO-GÓMEZ, M. F.; MANRÍQUEZ-NUÑEZ, O. M.; GONZÁLEZ-VIZCARRA, V. M.; GUEVARAFLORENTINO, O. F.; RAMÍREZ DE LEÓN, J. A. Effect of diets with different energy concentrations on growth performance, carcass characteristics and meat chemical composition of broiler chickens in dry tropics. SpringerPlus, Londres, v. 5, n. 1, p .1937-1944, 2016. DOI: $10.1186 / \mathrm{s} 40064-016-3608-0$

KAMRAN, Z.; SARWAR, M.; NISA, M.; MAHMOOD, S.; BABAR, M.E.;AHMED, S. Effect of low-protein diets having constant energy-to-protein ration on performance and carcass characteristics of broiler chickens from to thirty-five days of age. Poultry Science, Savoy, v. 87, n. 3, p. 468-474, 2008. DOI: 10.3382/ps.2007-00180

MAERTENS, L.; LUDO S.; MARC, R.; ARNO, A.; SASKIA, L.; VAN DER, A. A. The effect of different emulsifiers on fat and energy digestibility in broilers. European Symposium on Poultry Nutrition, Prague, v. 29, p. 1-4, 2015.

MARTINS, J. M. S.; FERNANDES, E. A.; BUENO, J. P. R.; CARVALHO, C. M. C.; LITZ, F. H.; MASCULI, A. L. S.; FAGUNDES, N. S.; SILVA, M. C. A.; SILVEIRA, M. M.; MORAES, C. A. Effect of nutrition on the body temperature and relative organ weights of broilers. Semina: Ciências Agrárias, Londrina, v. 36, n. 6, p. 45754588 , 2015. Supplement 2. DOI: $10.5433 / 1679-0359$

MEZA, S. K. L.; NUNES, R. V.; TSUTSUMI, C. Y.; SCHERER, C.; SAVOLDI, T. L. Efeito dos níveis de energia metabolizável e lisina digestível sobre o rendimento de carcaça de frangos de corte com 42 dias. Scientia Agraria Paranaensis, Marechal Cândido Rondon, v. 12, p. 420-424, 2015. Suplemento 1. DOI: 10.1818/sap.v12i0.9571

MURAKAMI, A. E.; GARCIA, E. R. M.; MARTINS, E. N.; MOREIRA, I.; SCAPINELLO, C.; OLIVEIRA, A. F. G. Efeito da inclusão de óleo de linhaça nas rações sobre o desempenho o os parâmetros ósseos de frangos de corte. Revista Brasileira de Zootecnia, Viçosa, v. 38, n. 7, p. 1256-1264, 2009. DOI: 10.1590/S151635982009000700014

NAGARGOJE, S. B.; DHUMAL, M. V.; NIKAM, M. G.; KHOSE, K. K. Effect of crude soy lecithin with or without lipase on performance and carcass traits, meat keeping quality and economics of broiler chicken. International Journal of Livestock Research, Wilmington, v. 6, n. 12, p. 46-54, 2016. DOI: 10.5455/ijlr.20161218124154

NAGATA, A. K.; RODRIGUES, P. B.; ALVARENGA, R. R.; ZANGERONIMO, M. G.; DONATO D. C. Z.; SILVA, J. H. V. Carcass characteristics of broilers at 42 days receiving diets with phytase in different energy and crude protein levels. Ciências e Agrotecnologia, Lavras, v. 35 , n. 3 , p. $575-581,2011$. DOI: $10.1590 /$ S141370542011000300020

NOGUEIRA, W. C. L.; VELÁSQUEZ, P. A. T.; FURLAN, R. L.; MACARI, M. Effect of dietary energy and stocking density on the performance and sensible heat loss of broilers reared under tropical winter conditions. Brazilian Journal of Poultry Science, Campinas, v. 15 , n. 1, p. 53-58, 2013. DOI: $10.1590 /$ S1516-635X2013000100009

PARK, J. H.; NGUYEN, D. H.; KIM, I. H. Effects of exogenous lysolecithin emulsifier supplementation on the growth performance, nutrient digestibility, and blood lipid profiles of broiler chickens. Japan Poultry Science Association, Tsukuba Ibaraki, v. 55, n. 3, p. 190-194, 2017. DOI: $10.2141 /$ jpsa.0170100

RAJU, M. V.L. N.; RAMARAO, S. V.; CHAKRABARTI, P. P.; RAO, B. V. S. K.; PANDA, A. K.; DEVI, P. B. L. A.; SUJATHA, V.; REDDY, J. R. C.; SUNDER, G. S.; PRASAD, R. B. N. Rice bran lysolecithin as a source of energy in broiler chicken diet. British Poultry Science, Londres, v. 52, n. 6, p. 769-774, 2011. DOI: 10.1080/00071668.2011.640929

REYES, M. E.; SALAS, C.; COON, C. N. Metabolizable energy requirements for broiler in different environmental temperatures. International Journal of Poultry Science, Faisalabad, v. 7, n. 7, p. 453-461, 2012. DOI: 10.3923/ ijps.2012.453.461

RICHARDS, M. P.; PROSZKOWIEC-WEGLARZ, M. Mechanisms regulating feed intake, energy expenditure, and body weight in poultry. Poultry Science, Savoy, v. 86 , n. 7 , p. $1478-1490,2007$. DOI: $10.1093 /$ ps/86.7.1478

ROLL, A. P.; LOPES, D. C. N.; AZAMBUJA, A.; PIRES, P. G. S.; XAVIER, E. G.; ROLL, V. F. B.; RUTZ, F. Efeito de diferentes níveis de energia da dieta no desempenho de frangos de corte entre os 43 e 48 dias de idade. Revista Portuguesa de Ciências Veterinárias, Lisboa, v. 106, n. 1, p. 577-580, 2011.

ROSTAGNO, O. S. Tabelas brasileiras para aves $e$ suínos. 4. ed. Viçosa: UFV. 2017.

SAKOMURA, N. K.; ROSTAGNO, H. S. Métodos de pesquisa em nutrição de monogástricos. 2. ed. Jaboticabal: FUNEP, 2016.

SAVOLDI, T. L.; NUNES, R. V.; SCHERER, C; TSUTSUMI, C. Y.; SCHENEIDERS, J. L.; MARQUES, M. F. G.; SCHONE, R. A.; MEZA, S. K. L. Níveis de energia metabolizável e lisina digestível para o desempenho de pintos de corte de 1 a 10 dias de idade. Scientia Agraria Paranaensis, Marechal Cândido Rondon, v. 11, p. 49-58, 2012. Suplemento 1. DOI: 10.18188/1983-1471/sap.v11nsupp49-58 
SILVA, E. T.; LEITE, D. G.; YURI, F.M.; NERY, F. S. G.; REGO, J. C. C.; ZANATTA. R. A.; SANTOS, S. A.; MOURA. V. V. Determinação do índice de temperatura e umidade (ITU) para produção de aves na mesorregião metropolitana de Curitiba - PR. Revista Acadêmica: Ciências Agrárias e Ambientais, Curitiba, v. 2, n. 3, p. 47-60, 2004. DOI: 10.7213/cienciaanimal.v2i3.15099

SLOMINSKI, B. A.; MENG, X.; JIA, W.; GUENTER, W.; JONES, O. The effect of lipase, amylase and protease addition on growth performance and nutrient digestion in young broiler chickens. World's Poultry Science Association, Beekbergen, EPC 2006 - 12th European Poultry Conference, Verona, Italy, 10-14 September, 2006. paper 240 ref.17. Disponível em: https://pdfs.semanticscholar.org/0ce2/391b5b7a159c f4f4ae4fafdd3fc08731e19c.pdf. Acesso em: 23 maio 2019.

UPADHAYA, S. D.; PARK, J. W.; PARK, J. H.; KIM, I. H. Efficacy of 1,3-diacylglycerol as a fat emulsifier in low-density diet for broilers. Poultry Science, Savoy, v. 96, n. 6, p. $1672-1678,2017$. DOI: $10.3382 /$ ps/pew425

WANG, J. P.; ZHANG, Z. F.; YAN, L.; KIM, I. H. Effects of dietary supplementation of emulsifier and carbohydrase on the growth performance, serum cholesterol and breast meat fatty acids profile of broiler chickens. Animal Science Journal, Cambridge, v. 87, n. 2, p. 250-256, 2016. DOI: 10.1111/asj.12412
WANG, Y.; YAN, J.; ZHANG, X.; HAN, B. Tolerance properties and growth performance assessment of Yarrowia lipolytic lipase in broilers. Journal of Applied Animal Research, Abingdon, v. 46, n. 1, p. 486-491, 2017. DOI: $10.1080 / 09712119.2017 .1340298$

ZAEFARIAN, F.; ROMERO, L. F.; RAVINDRAN, V. Influence of high dose of phytase and an emulsifier on performance, apparent metabolisable energy and nitrogen retention in broilers fed on diets containing soy oil or tallow. British Poultry Science, Abingdon, v. 56, n. 5, p. 590-597, 2015. DOI: 10.1080/00071668.2015.1067878

ZAMPIGA, M.; MELUZZI, A.; SIRRI, F. Effect of dietary supplementation of lysophospholipids on productive performance, nutrient digestibility and carcass quality traits of broiler chickens. Italian Journal of Animal Science, Abingdon, v. 15, n. 3, p. 521-528, 2016. DOI: 10.1080/1828051X.2016.1192965

ZHANG, B.; HAITAO, L.; ZHAO, D.; GUO, Y.; BARRI, A. Effect of fat type and lysophosphatidylcholine addition to broiler diets on performance, apparent digestibility of fatty acids, and apparent metabolizable energy content. Animal Feed Science and Technology, Amsterdam, v. 163, n. 2, p. 177-184, 2011. DOI: 10.1016/j.anifeedsci.2010.10.004

ZHAO, P. Y.; KIM, I. H. Effect of diets with different energy and lysophospholipids levels on performance, nutrient metabolism, and body composition in broilers. Poultry Science, Savoy, v. 96, n. 5, p. 1341-1347, 2017. DOI: $10.3382 /$ ps/pew469 